\title{
Partial substitution of fishmeal with soybean protein-based diets for dourado Salminus
}

\section{brasiliensis}

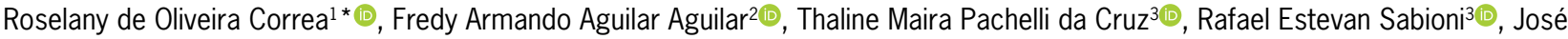 \\ Eurico Possebon Cyrino ${ }^{3}$
}

${ }^{1}$ Embrapa Amazônia Oriental, Tv. Dr. Enéas Pinheiro, s/n 66017-970 - Belém, PA - Brasil.

${ }^{2}$ Fundación Universitaria Agraria de Colombia/Facultad de Ciencias Agropecuarias, Calle 170 No 54A - 10 Bogotá Colombia.

${ }^{3}$ Universidade de São Paulo/ESALQ - Depto. de Zootecnia, Av. Pádua Dias, 11 - 13418-900 - Piracicaba, SP - Brasil.

*Corresponding author <roselany.correa@embrapa.br>

Edited by: Antonio Faciola

Received February 09, 2018

Accepted September 24, 2018
ABSTRACT: Cost and environmental restrictions limit the use of fishmeal (FM) in aquafeeds and plant protein (PP) sources. Soybean by-products are important alternative; however, their antinutritional factors may reduce fish growth. This study evaluates the effect of FM substitution for PP (soybean meal and soy protein concentrate) in diets of dourado (Salminus brasiliensis), a promising species for fish farming and empirically considered highly tolerant to PP-based diets. A control diet was formulated to contain $20 \%$ of fishmeal and $61 \%$ of plant protein (SBM) and other five diets with decreasing FM graded levels (16\%, $12 \%, 8 \%, 4 \%, 0 \%$ ), which were replaced by soybean protein concentrate (SPC), comprising six treatments and four replicates. Fifteen dourados $(6.73 \pm 0.2 \mathrm{~g})$ were stocked into $200 \mathrm{~L}$ tanks in a recirculating system, fed with experimental diets three times a day to apparent satiation for 90 days. Growth performance, food conversion ratio, protein efficiency ratio and protein retention efficiency of fish were impaired when FM substitution exceeded $13.05 \%$ (the broken line analysis method). Histological analysis of intestinal mucosa showed a decrease in villus height when fishmeal was totally replaced by PP, which probably impaired digestive functions of fish and reflected in a severe loss on growth performance.

Keywords: enteritis, aquaculture, protein source, gastrointestinal tract, nutrition

\section{Introduction}

Fishmeal (FM) is an important protein source in animal feeds, especially for carnivorous and marine finfish; however, limited supply of FM leads to the substitution by plant protein sources (PP), an inexpensive and sustainable alternative (Magalhães et al., 2016). Some studies report a substantial reduction in dietary FM using PP without compromising growth performance, nutrients digestibility and feed utilization (Watson et al., 2014; Minjarez-Osorio et al., 2016; Yaghoubi et al., 2016; Rossi et al., 2017). In general, a deficient amino acid profile and antinutritional factors (ANFs) limit high inclusions of these feedstuffs into diets, especially for high trophic levels, carnivorous fish (Gilani et al., 2012).

Soybean by-products, mainly defatted soybean meal, have been widely used as surrogate protein source to fishmeal, although the main ANFs, such as enzyme inhibitors and saponins, have been frequently associated to low digestibility of diets. ANFs can be inactivated by processing techniques (grinding, cooking, extracting, fermenting) yielding quality products (Solomon et al., 2017), such as ethanol-extracted soybean protein concentrate (SPC), an alternative protein source for carnivorous fish diets (Collins et al., 2013; Bañuelos-Vargas, 2014; Bansemer et al., 2015). Except for polysaccharides, most carbohydrates are washed off from SPC during processing; however, peptidic compounds are preserved, increasing crude protein contents of feedstuff and favoring its use in dense diets.
The Neotropical, carnivorous Chacin dourado (Salminus brasiliensis), a highly promising species for fish farming, is empirically considered highly tolerant to plant protein-based diets. However, fish species have distinct tolerance to graded levels of dietary soybean byproducts. This study evaluates effects of reducing FM on diets for juvenile dourados, substituting this feedstuff for PP (soybean meal and soybean protein concentrate). The safe threshold for replacement of FM for PP was defined in a growth performance trial and tentatively related to effects of diets on liver histology and anterior intestine of the species.

\section{Materials and Methods}

Trials were performed according to regulations for experimentation with live animals set by "Comissão de Ética no Uso de Animais" (CEUA - Animal Ethic and Use Committee) protocol \# 2014-01.

\section{Growth performance}

A practical diet was formulated with $20 \%$ fishmeal (FM) and $61 \%$ soybean meal (SBM) as protein sources (control). Five other diets (T1 to T5), with the same protein for gross energy ratio, were formulated with decreasing graded levels $(16 \%, 12 \%, 8 \%, 4 \%$ and $0 \%)$ of $\mathrm{FM}$, which was replaced by soy protein concentrate (SPC, Selecta S/A, Goiânia, GO, Brazil). A high quality protein source in which the amino acid profile is similar to FM, except for methionine deficiency (Table 1). Experimental diets were extruded, oven dried (forced air oven; $45^{\circ} \mathrm{C} ; 24 \mathrm{~h}$ ), stored in plastic bags, and frozen $\left(-18^{\circ} \mathrm{C}\right)$ until use. 
Table 1 - Diet formulations and chemical composition of dietary treatments ( $\mathrm{g} \mathrm{kg}^{-1} \mathrm{dry}$ diet).

\begin{tabular}{|c|c|c|c|c|c|c|}
\hline \multirow{2}{*}{ Ingredients $\left(\mathrm{g} \mathrm{kg}^{-1}\right)$} & \multicolumn{6}{|c|}{ Diets } \\
\hline & Control & $\mathrm{T} 1$ & $\mathrm{~T} 2$ & $\mathrm{~T} 3$ & T4 & T5 \\
\hline Fishmeal (61.42\% PB) & 200.00 & 160.00 & 120.00 & 80.00 & 40.00 & 0.00 \\
\hline $\mathrm{SPC}^{1}(64.14 \% \mathrm{~PB})$ & 0.00 & 40.00 & 80.00 & 120.00 & 160.00 & 200.00 \\
\hline Soybean meal & 610.90 & 616.70 & 622.60 & 628.40 & 631.30 & 618.00 \\
\hline Soybean oil & 123.90 & 132.30 & 135.20 & 137.80 & 142.00 & 150.50 \\
\hline Lysine & 10.00 & 10.00 & 10.00 & 10.00 & 10.00 & 13.00 \\
\hline DL- methionine & 5.10 & 5.30 & 5.60 & 5.90 & 6.30 & 6.70 \\
\hline Dicalcium phosphate & 39.90 & 25.10 & 16.20 & 7.30 & 0.00 & 1.60 \\
\hline Premix ${ }^{2}$ & 10.00 & 10.00 & 10.00 & 10.00 & 10.00 & 10.00 \\
\hline $\mathrm{BHT}^{3}$ & 0.20 & 0.20 & 0.20 & 0.20 & 0.20 & 0.20 \\
\hline \multicolumn{7}{|l|}{ Chemical composition $\left(\mathrm{g} \mathrm{kg}^{-1}\right)$} \\
\hline Dry matter (DM) & 968.2 & 970.7 & 955.6 & 970.7 & 961.4 & 958.9 \\
\hline Crude protein (CP) & 458.2 & 468.8 & 466.3 & 463.8 & 458.6 & 455.4 \\
\hline Lipids (L) & 51.6 & 54.5 & 69.6 & 61.8 & 55.8 & 65.3 \\
\hline Crude fiber (CF) & 22.6 & 29.9 & 28.8 & 24.6 & 35.6 & 41.7 \\
\hline Ash (A) & 104.1 & 85.5 & 76.7 & 66.1 & 76.7 & 56.7 \\
\hline Nitrogen-free extract (NFE) ${ }^{4}$ & 331.7 & 332.0 & 314.2 & 354.4 & 334.7 & 339.8 \\
\hline Crude energy (kcal kg-1) & 4312 & 4354 & 4207 & 4199 & 4297 & 4198 \\
\hline
\end{tabular}

Juveniles of dourado $(6.73 \pm 0.2 \mathrm{~g})$ were adapted for $7 \mathrm{~d}$ to a thermo-regulated, closed loop wet laboratory system, randomly stocked in 24 polyethylene tanks 1300 L; 15 fish per tank) under controlled photoperiod condition (10 light:14 h dark) (Heinen, 1998). The fish were fed to apparent satiation, with three daily meals, $7 \mathrm{~d}$ a week for $90 \mathrm{~d}$ with the experimental diets in a totally randomized experiment design $(n=4)$. We monitored dissolved oxygen $\left(4.38 \pm 0.35 \mathrm{mg} \mathrm{L}^{-1}\right)$, water temperature $\left(25.19 \pm 0.26^{\circ} \mathrm{C}\right)$ and $\mathrm{pH}(7.93 \pm 0.05)$ daily with a multiparameter Horiba U-50 electronic water quality probe.

At the end of trial, fish were euthanized by anesthetic overdose (benzocaine; $10 \mathrm{mg} \mathrm{L}^{-1}$, cold water). Eight fish (two per tank) were randomly sampled per treatment and dissected and their livers were excised and weighted to calculate hepatosomatic index. Distal portion of the left hepatic lobe and proximal intestine were collected and fixed in buffered paraformaldehyde $(4 \%, \mathrm{pH} 7.4)$ for the histological analyses. Another three fish per tank were stored at $-20^{\circ} \mathrm{C}$ for the chemical composition analysis.

Growth performance was evaluated by calculating: weight gain: WG $(\mathrm{g})$ = initial weight - final weight; feed intake: FI (\% fish weight) $=100 \times$ (amount of feed consumed / average tank biomass ${ }^{-1}$ ); feed conversion ratio: $\mathrm{FCR}=$ (feed intake) / (weight gain); protein efficiency ratio: PER $(\%)=[($ weight gain / dietary protein intake) $x$ 100]; protein retention efficiency: $\operatorname{PRE~}(\%)=$ [(protein gain in tissue / dietary protein consumed) $\left.{ }^{*} 100\right]$; hepatosomatic index: HSI $(\%)=100 \times[($ liver weight $) /$ (total body weight)]. Survival rate (SR) was calculated as the percentage of relationship between recorded casualties and the number of fish initially stocked.

\section{Histological analyses}

Sampled excisions were processed using standard histological techniques (Cruz et al., 2014; Moretti et al., 2014); six blade-mounted sections per fish were stained with haematoxylin and eosin (H.E.). The morphometric analysis of proximal intestine comprised: measurement of mucosal fold height $(\mathrm{FH})$, fold thickness (FT), and muscular layer thickness (MT). Goblet cells were counted on six fields per section. For the morphometric evaluation of liver, the area of ten hepatocytes nucleus per section was measured, as indicator of hepatic activity (Ostaszewska et al., 2005). All histological analyses and cell counting were done under a light microscope coupled to an image analysis system.

\section{Chemical analyses}

Ingredients, diets and fish carcasses were analyzed for dry matter (DM), crude protein (CP), lipids (L), crude fiber $(\mathrm{CF})$, ash $(\mathrm{A})$ and gross energy contents according to the AOAC (2000) methodology.

\section{Statistical procedures}

Data were analyzed by one-way ANOVA and residual normality and homogeneity of variance were assessed using the Kolmogorov-Smirnov and BrownForsythe tests, respectively. The Tukey HSD post-hoc analyses were used to determine differences between 
means of dietary treatments. The optimal level for better growth and weight gain data was defined by the broken-line regression analysis (Portz et al., 2000). Significance level for all statistical comparisons was defined at $\alpha=0.05$. The statistical analyses were performed using GLM of statistical software systems SAS v.9 (Statistical Analysis System Institute, Cary, NC, USA) and R (The R Foundation for Statistical Computing, Vienna, Austria).

\section{Results}

Increasing substitution of fishmeal by soybean protein sources reduced weight gain of dourado ( $p<$ 0.05); feed conversion ratio (FCR) worsened in T4 and $\mathrm{T} 5$ fed fish. The lowest protein efficiency ratio (PER) was observed in fish fed $\mathrm{T} 5$ diet which was not statistically different from T4 group (Table 2). At the end of the trial, feed intake (FI) and hepatosomatic index (HSI) of dourado were not affected by experimental diets. Reduction of fishmeal on experimental diets reduced crude protein on carcass composition; however, it did not affect dry matter, lipids and ash (Table 3).

The proximal intestine of fish fed the control diet had simple folds protracted to lumen, such as both pri- mary (greater height of folds) and secondary folds. The mucosa comprised a simple columnar epithelium, supported by the lamina propria, a thin layer of connective tissue. The most populous epithelial cell type was absorptive enterocytes, while numerous goblet cells were sparsely distributed between them. The supporting mucosa, comprised two layers of smooth muscle: an circular inner and a longitudinal outer layer (Figure 2A). The morphometric analyses of intestine revealed that dourado fed $\mathrm{T} 5$ diet presented the lowest mucosal fold height (FH) (Table 4). Although alterations were not detected on HSI $(p>0.05)$, dourado fed T5 diet presented lipid depots on hepatocytes cytoplasm. The area of hepatocytes nuclei was not affected by increasing plant protein inclusions $(p>0.05)$.

\section{Discussion}

Changes in diet formulation from FM- to PPbased feedstuffs may cause adverse effects on growth performance of fish. Under the experimental conditions in our study, dourado fed control diet (61\% SBM) presented growth performance and protein efficiency ratio (WG $=55.15 \mathrm{~g}$ and PER $=1.87$ ) similar to reports in

Table 2 - Growth performance of dourado fed experimental diets.

\begin{tabular}{lcccccc}
\hline & Control & T1 & T2 & T3 & T4 & T5 \\
\hline WO & $6.83 \pm 0.29$ & $6.69 \pm 0.18$ & $6.71 \pm 0.17$ & $6.86 \pm 0.15$ & $6.71 \pm 0.24$ & $6.60 \pm 0.03$ \\
WG & $55.15 \pm 2.45^{\mathrm{a}}$ & $52.95 \pm 4.83^{\mathrm{a}}$ & $49.17 \pm 2.42^{\mathrm{ab}}$ & $35.89 \pm 4.85^{\mathrm{bc}}$ & $26.27 \pm 2.17^{\mathrm{cd}}$ & $11.93 \pm 2.11^{\mathrm{d}}$ \\
FI & $2.11 \pm 0.14$ & $2.12 \pm 0.03$ & $2.14 \pm 0.02$ & $2.29 \pm 0.27$ & $2.33 \pm 0.15$ & $1.92 \pm 0.26$ \\
FCR & $1.18 \pm 0.08^{\mathrm{a}}$ & $1.21 \pm 0.02^{\mathrm{a}}$ & $1.24 \pm 0.02^{\mathrm{a}}$ & $1.57 \pm 0.27^{\mathrm{a}}$ & $1.68 \pm 0.12^{\mathrm{ab}}$ & $2.70 \pm 0.56^{\mathrm{b}}$ \\
PER & $1.87 \pm 0.13^{\mathrm{a}}$ & $1.76 \pm 0.03^{\mathrm{ab}}$ & $1.73 \pm 0.03^{\mathrm{ab}}$ & $1.47 \pm 0.19^{\mathrm{ab}}$ & $1.31 \pm 0.09^{\mathrm{bc}}$ & $0.87 \pm 0.15^{\mathrm{c}}$ \\
PRE & $33.39 \pm 2.28^{\mathrm{a}}$ & $30.52 \pm 1.24^{\mathrm{ab}}$ & $30.10 \pm 0.57^{\mathrm{ab}}$ & $25.51 \pm 3.34^{\mathrm{abc}}$ & $23.11 \pm 1.82^{\mathrm{bc}}$ & $17.32 \pm 1.69^{\mathrm{c}}$ \\
HSI & $1.82 \pm 0.04$ & $1.81 \pm 0.03$ & $1.79 \pm 0.02$ & $1.79 \pm 0.07$ & $1.77 \pm 0.07$ & $2.09 \pm 0.21$ \\
SR & $100 \pm 0.00^{\mathrm{a}}$ & $98.33 \pm 1.67^{\mathrm{a}}$ & $98.33 \pm 1.67^{\mathrm{a}}$ & $90 \pm 5.77^{\mathrm{ab}}$ & $91.67 \pm 8.33^{\mathrm{ab}}$ & $66.67 \pm 13.88^{\mathrm{b}}$ \\
\hline
\end{tabular}

$\mathrm{WO}=$ Initial weight, $\mathrm{g} ; \mathrm{WG}=$ Weight gain, $\mathrm{g} ; \mathrm{Fl}=$ Feed intake, $\%$ average biomass weight $\left.\mathrm{d}^{-1}\right) ; \mathrm{FCR}=$ feed conversion ratio; PER = protein efficiency ratio; PRE $=$ protein retention efficiency, \%); HSI = hepatossomatic index, $\%$ and $S R=$ survival rate, $\%$. Data are means \pm S.E.M $(n=4)$. Values in the same line with different letters means significantly different $(p<0.05)$.

Table 3 - Carcass composition of dourado (wet-basis).

\begin{tabular}{lccccccc}
\hline & \multicolumn{7}{c}{ Diets } \\
\cline { 2 - 8 } & Initial & Control & T1 & T2 & T3 & T4 & T5 \\
\cline { 2 - 8 } Moisture & 767.6 & $661.2 \pm 2.31$ & $661.4 \pm 1.72$ & $655.9 \pm 1.73$ & $677.4 \pm 1.35$ & $672.6 \pm 0.29$ & $692.2 \pm 2.35$ \\
Crude protein & 164.3 & $177.20 \pm 2.83^{\mathrm{a}}$ & $172.02 \pm 4.94^{\mathrm{a}}$ & $172.47 \pm 3.12^{\mathrm{a}}$ & $170.33 \pm 3.08^{\mathrm{a}}$ & $171.60 \pm 2.39^{\mathrm{a}}$ & $157.10 \pm 1.87^{\mathrm{b}}$ \\
Lipids & 239 & $117.87 \pm 8.87$ & $107.87 \pm 15.34$ & $138.95 \pm 5.20$ & $115.12 \pm 12.79$ & $118.72 \pm 5.28$ & $104.23 \pm 16.35$ \\
Ash & 395 & $32.27 \pm 6.72$ & $40.40 \pm 5.06$ & $35.12 \pm 6.91$ & $38.22 \pm 4.66$ & $37.15 \pm 3.64$ & $23.07 \pm 6.92$ \\
\hline
\end{tabular}

Data are means \pm S.E.M $(n=4)$. Values in the same row with different letters are significantly different $(p<0.05)$.

Table 4 - Morphometric analyses used to assess the degree of alterations on intestinal mucosa of dourado.

\begin{tabular}{|c|c|c|c|c|c|c|}
\hline \multirow{2}{*}{ Measures ( $\mu \mathrm{m})$} & \multicolumn{6}{|c|}{ Diets } \\
\hline & Control & $\mathrm{T} 1$ & $\mathrm{~T} 2$ & T3 & $\mathrm{T} 4$ & $\mathrm{~T} 5$ \\
\hline$\overline{\mathrm{FH}}$ & $77.95 \pm 23.44^{a}$ & $45.12 \pm 25.87^{a b}$ & $68.66 \pm 30.97^{a b}$ & $88.6 \pm 36.20^{a b}$ & $63.16 \pm 31.35^{\mathrm{ab}}$ & $29.96 \pm 30.41^{b}$ \\
\hline FT & $70.25 \pm 12.08$ & $55.29 \pm 6.95$ & $82.27 \pm 20.13$ & $50.11 \pm 7.22$ & $47.63 \pm 4.95$ & $69.55 \pm 11.55$ \\
\hline MT & $129.94 \pm 10.21$ & $155.09 \pm 9.33$ & $144.45 \pm 10.69$ & $147.69 \pm 6.30$ & $141.73 \pm 6.56$ & $123.53 \pm 10.05$ \\
\hline Amount of GC & $33.00 \pm 7.13$ & $28.50 \pm 7.94$ & $22.25 \pm 6.41$ & $22.25 \pm 6.57$ & $23.50 \pm 4.97$ & $38.50 \pm 10.09$ \\
\hline
\end{tabular}


the literature in which experimental diets had lower PP content, meaning a high tolerance of this species to this feedstuff. Dourado $\left(\mathrm{W}_{0}=5.68 \mathrm{~g}\right)$ fed diets $(45 \% \mathrm{CP}$ and $4098 \mathrm{kcal} \mathrm{kg}^{-1}$ ) based on FM (41\% of diet) and casein $(16 \%)$ as dietetic protein sources had $39 \mathrm{~g}$ of WG and a protein retention of $26.58 \%$, in $94 \mathrm{~d}$ (Teixeira et al., 2010). Machado-Neto et al. (2015) conducted a 60-day experiment and found that dourado $\left(\mathrm{W}_{0}=13.3 \mathrm{~g}\right) \mathrm{fed}$ a control diet (44\% CP and $4967.99 \mathrm{kcal} \mathrm{kg}^{-1}$ ) based on FM (32\% of diet), poultry by-product meal (20\%) and SBM (23\%), obtained a WG of $55.6 \mathrm{~g}$ and a PER of 1.1 . Lorenz et al. (2018) reported WG $26.02 \mathrm{~g}$ and PER 2.22, when dourado $\left(\mathrm{W}_{0}=4.57 \mathrm{~g}\right)$ were fed a control diet $(45 \%$ $\mathrm{CP}$ and $4793.64 \mathrm{kcal} \mathrm{kg}^{-1}$ ) based on FM (28\% of diet), corn gluten meal $(13 \%)$ and SBM (31 \%) for $61 \mathrm{~d}$. All reports mentioned above presented diets with the same protein for gross energy ratio (0.01), as well as experimental diets used in this study.

Results also show that, although dourado has high tolerance to PP on diets, fishmeal could not be completely substituted without impairing growth performance and even survival rate, which decreased from day 42 of the trial onward, particularly when fish were fed T4 and $\mathrm{T} 5$ diets.

As defined by the Broken-line model analysis, up to $13.05 \%$ of FM (about $10 \%$ of dietetic protein) could be safely substituted by SPC in experimental diets (Figure 1). Above 13.05\%, unbalance of amino acids and fractions of ANFs possibly present in this feedstuff were especially detrimental to dourado. Similar result was reported for Silvery-black porgy (Sparidentex hasta), a carnivorous marine fish species sensitive to high inclusion of soybean feedstuffs in diets. Silvery-black porgy tolerates a maximum dietary FM replacement of $16 \%$ when crystalline essential amino acids were supplemented, without impairing WG (Yaghoubi et al., 2016). Conversely, Walker et al. (2012) observed that in diets for juvenile Atlantic cod (Gadus morhua), a highly piscivorous species, FM could be entirely replaced by SPC without affecting growth and feed conversion. In this study, all experimental diets were supplemented with methionine $(0.50-0.67 \%)$ - the limiting amino acid in soybean by products - which did not prevent lower weight gain when FM was totally replaced by PP.
Decreasing FM content affected FCR of dourado and the worst values were recorded when FM was completely replaced by PP in diets (T5; Table 2). Dietary plant protein usually has poor palatability compared to animal protein-based diets, due to the presence of various plant secondary metabolites, such as saponins in soybeans (Silva-Carrillo et al., 2012; Wang et al., 2017).

The highest protein retention efficiency (PRE) were recorded for fish fed diets with higher FM contents, which strengthen the Broken-line analysis prediction, currently a fairly predictable phenomenon. Fish fed $\mathrm{T} 5$ diet reduced protein retention in carcass. Dietary ANFs, especially of peptidic nature (protease inhibitors and lectins), may also affect dietary nutrient digestibility. Soybean protease inhibitors - Kunitz inhibitor of trypsin and Bowman-Birk inhibitor of chymotrypsin and trypsin - cause immediate hypersecretion of trypsin and chymotrypsin as a compensatory mechanism to adapt the organism to digest effectively ANF-containing feeds that may thus enhance endogenous losses of sulfur-containing amino acids, causing an important nutritional

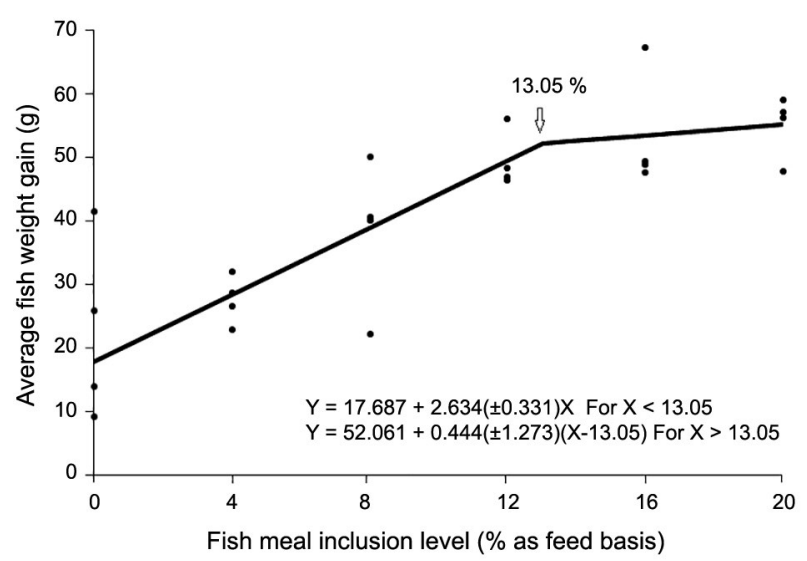

Figure 1 - Effect of fish inclusion level on growth of Dourado (Salminus brasiliensis) in a 90-day growth trial. Continue line is a fitted broken line model $\left(R^{2}=0.988\right)$. Standard error of parameter (slopes) estimates are between parenthesis. The slope for $X>13.05$ was no significantly different from zero $(p<0.05)$.

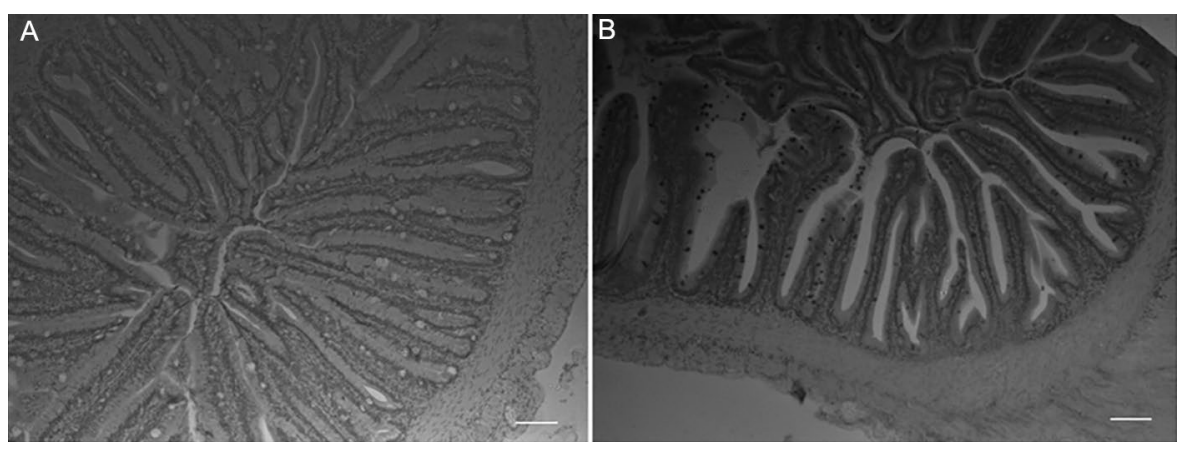

Figure 2 - Intestinal folds of dourado fed control diet (A) and T5 diet (B) (H.E. staining). Scale bars $=100 \mu \mathrm{m}$. 

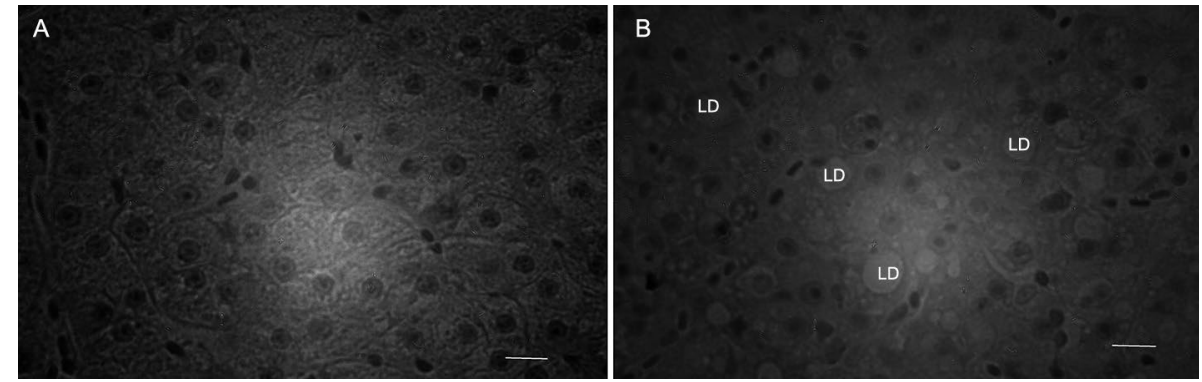

Figure 3 - Cross section of liver of dourado fed control diet (A) and T5 diet (B). Hepatocyte cytoplasm stored lipid droplets (LD) (H.E. staining). Scale bars $=100 \mu \mathrm{m}$.

impact, since soybeans are naturally deficient in this amino acids. After prolonged exposure and a given species-specific concentration, ANFs can cause pancreatic exhaustion, reducing production of pancreatic enzymes (Hart et al., 2010). All these effects impair fish growth performance.

Lower crude protein content in carcass of juvenile dourado $(p>0.05)$ (Table 3$)$ indicates that T5 diet may have less digestible energy due to antinutritional factors (enzyme inhibitors, nonstarch polysaccharides - NSP) on plant sources, which impair nutrients digestibility, especially proteins and lipids, affecting fish growth ( $\mathrm{Li}$ et al., 2015). Unbalanced amino acid concentrations in a diet increase protein degradation and protein turnover (Kumar et al., 2012). In addition, reduction of intestinal area recorded for fish fed this diet, as discussed ahead, may have increased the species protein requirement for maintenance.

Fish fed T5 diets also had structural changes of intestinal mucosa and reduced digestive capacity (Table 4 ; Figure 2B). Reduction of the superficial area of intestinal mucosa had reduced membrane digestion, both cavitary and brush border digestions are interdependent. Cavitary digestion is insufficient to allow complete assimilation of food and activation of some zymogens require direct contact with intestinal wall (Kuzmina, 2008). In addition, brush border digestion increases the rate of cavitary hydrolysis because of subsequent absorption of intermediary products of hydrolysis, which inhibits pancreatic enzyme activities by accumulation in the intestinal lumen (Ugolev and De Laey, 1973). Fish fed the other experimental diets did not differ from control.

The anterior intestine is responsible for circa $80 \%$ of protein absorption (Wilson and Castro, 2011); therefore, any disturbance on the mucosal integrity results in poor nutrient absorption and, consequently, reduced fish growth (Wang et al., 2017). Dourado fed diets containing low or no FM had reduced intestinal mucosa area, presumably an energy conservation mechanism, as these low-quality diets fail to meet their energetic needs. Thus, limited digestibility and absorption of dietary nutrients is probably related to factors that impair physiological processes, such as enzyme production or activation of nutrient transporters.
Although the hepatosomatic index (HSI) was not altered by increasing dietary PP levels $(p>0.05)$ in this study, the highest value was observed on fish fed T5 diet. Hepatocytes of dourado fed the control diet were regularly shaped with visible cell membranes. Some nuclei located at the cell periphery and some poor pyknotic nuclei were also detected. Dourado fed T5 diet presented lipid depots on hepatocytes cytoplasm that dislocated the nucleus to the cell periphery (Figure 3) due to unbalanced nutrients in diets. Sevgili et al. (2015) related this kind of changes in the liver of fish fed plant protein-based diets with phosphorus deficiency.

\section{Conclusion}

Dourado fish are tolerant to high inclusion of PP in diets; nevertheless, the entire replacement FM is not recommended, even using soybean protein concentrate as surrogate feedstuff. In this study, up to $13.05 \%$ of FM could be replaced by SPC and above this level, feed utilization was impaired and amino acid profile unbalanced, resulting in severe growth reduction.

\section{Acknowledgements}

The authors are thankful to Fundação de Amparo à Pesquisa do Estado de São Paulo (FAPESP) for granting research funds (grant \# 2012/19549-0). The authors also thank Dr. Carlos Tadeu dos Santos Dias for his assistance with the statistical analysis.

\section{Authors' Contributions}

Conceptualization: Cyrino, J.E.P.; Corrêa, R.O. Data Acquisition: Corrêa, R.O. Data Analysis: Corrêa, R.O.; Cruz, T.M.P.; Aguilar, F.A.A.; Sabione, R.E. Design of Methodology: Cyrino, J.E.P.; Corrêa, R. Writing and Editing: Corrêa, R.O.

\section{References}

Association of Official Analytical Chemists - International [AOAC]. 2000. Official Methods of Analysis. 17ed. AOAC, Gaithersburg, MD, USA. 
Bansemer, M.S.; Forder, R.E.A.; Howarth, G.S.; Suitor, G.M.; Bowyer, J.; Stone, D.A.J. 2015. The effect of dietary soybean meal and soy protein concentrate on the intestinal mucus layer and development of subacute enteritis in Yellowtail Kingfish (Seriola lalandi) at suboptimal water temperature. Aquaculture Nutrition 21: 300-310.

Bañuelos-Vargas, I.; López, L.M.; Pérez-Jiménez, A.; Peres, H. 2014. Effect of fishmeal replacement by soy protein concentrate with taurine supplementation on hepatic intermediary metabolism and antioxidant status of totoaba juveniles (Totoaba macdonaldi). Comparative Biochemistry and Physiology - Part B 170: 18-25.

Collins, S.A.; Øverland, M.; Skrede, A.; Drew, M.D. 2013. Effect of plant protein sources on growth rate in salmonids: meta-analysis of dietary inclusion of soybean, pea and canola/rapeseed meals and protein concentrates. Aquaculture 400-401: 85-100.

Cruz, T.M.P.; Moretti, D.B.; Nordi, W.M.; Cyrino, J.E.P.; MachadoNeto, R. 2014. Intestinal epithelium of juvenile dourado Salminus brasiliensis (Cuvier, 1816) fed diet with lyophilized bovine colostrum. Aquaculture Research 47: 561-569.

Gilani, S.; Xiao, C.W.; Cockell, K.A. 2012. Impact of antinutritional factors in food proteins on the digestibility of protein and the bioavailability of amino acids and on protein quality. British Journal of Nutrition 108: S315-S332.

Hart, S.D.; Bharadwaj, A.S.; Brown, P.B. 2010. Soybean lectins and trypsin inhibitors, but not oligosaccharides or the interactions of factors, impact weight gain of rainbow trout (Oncorhynchus mykiss). Aquaculture 306: 310-314.

Heinen, J.M. 1998. The progressive fish-culturist light control for fish tanks. The Progressive Fish-Culturist 60: 323-330.

Kumar, V.; Makkar, H.P.S.; Becker, K. 2012. Evaluations of the nutritional value of Jatropha curcas protein isolate in common carp (Cyprinus carpio L.). Journal of Animal Physiology and Animal Nutrition 96: 1030-1043.

Kuzmina, V.V. 2008. Classical and modern concepts in fish digestion. p. 85-154. In: J. Cyrino, E.P.; Bureau, D.; Kapoor, B.G., eds. Feed and digestive functions in fishes. Science Publishers, Enfield, NH, USA.

Li, P.Y.; Wang, J.Y.; Song, Z.D.; Zhang, L.M.; Zhang, H.; Li, X.X.; Pan, Q. 2015. Evaluation of soy protein concentrate as a substitute for fishmeal in diets for juvenile starry flounder (Platichthys stellatus). Aquaculture 448: 578-585.

Lorenz, E.K.; Barone, R.C.S.; França, W.G.; Sabioni, R.E.; Koch, J.F.A.; Cyrino, J. E.P. 2018. Performance, hematology and immunology of Salminus brasiliensis fed diets containing swine liver hydrolysate. Aquaculture 483: 46-52.

Machado-Neto, R.; Moretti, D.B.; Nordi, W.M.; Cruz, T.M.P.; Cyrino, J.E.P. 2015. Growth performance of juvenile pacu (Piaractus mesopotamicus) and dourado (Salminus brasiliensis) fed with lyophilized bovine colostrum. Aquaculture Research 47: 3551-3557.

Magalhães, R.; Lopes, T.; Martins, N.; Díaz-Rosales, P.; Couto, A.; Pousão-Ferreira, P.; Oliva-Teles, A; Peres, H. 2016. Carbohydrases supplementation increased nutrient utilization in white seabream (Diplodus sargus) juveniles fed high soybean meal diets. Aquaculture 463: 43-50.

Minjarez-Osorio, C.; Castillo-Alvarado, S.; Gatlin, D.M.; GonzálezFélix, M.L.; Perez-Velazquez, M.; Rossi, W. 2016. Plant protein sources in the diets of the sciaenids red drum (Sciaenops ocellatus) and shortfin corvina (Cynoscion parvipinnis): a comparative study. Aquaculture 453: 122-129.
Moretti, D.B.; Nordi, W.M.; Cruz, T.M.P.; Cyrino, J.E.; MachadoNeto, R. 2014. Histochemical distribution of intestinal enzymes of juvenile pacu (Piaractus mesopotamicus) fed lyophilized bovine colostrum. Fish Physiology and Biochemistry 40: 1487-1493.

Ostaszewska, T.; Dabrowski, K.; Palacios, M. E.; Olejniczak, M.; Wieczorek, M. 2005. Growth and morphological changes in the digestive tract of rainbow trout (Oncorhynchus mykiss) and pacu (Piaractus mesopotamicus) due to casein replacement with soybean proteins. Aquaculture 245: 273-286.

Portz, L.; Dias, C.T.S.; Cyrino, J.E.P. 2000. A broken-line model to fit fish nutrition requirements. Scientia Agricola 57: 601-607.

Rossi, W.; Ju, M.; Hume, M.E.; Tomasso, J.R.; Gatlin, D.M. 2017. Nutrition of red drum, Sciaenops ocellatus L.: an additional evaluation of the effects of soya-based diets and supplemental prebiotic. Aquaculture Research 48: 5224-5234.

Sevgili, H.; Kurto lu, A.; Oikawa, M.; Aksoy, A.; Kocakaya, S.; Öztürk, E.; Uysal, R.; Gündüz Oruç, H. 2015. A combination of corn gluten and soybean meal as a substitute for fishmeal in diets of turbot (Scophthalmus maximus Linnaeus, 1758) in brackish water. Journal of Applied Ichthyology 31: 355-361.

Silva-Carrillo, Y.; Hernández, C.; Hardy, R.W.; González-Rodríguez, B.; Castillo-Vargasmachuca, S. 2012. The effect of substituting fishmeal with soybean meal on growth, feed efficiency, body composition and blood chemistry in juvenile spotted rose snapper Lutjanus guttatus (Steindachner, 1869). Aquaculture 364-365: 180-185.

Solomon, S.G.; Okomoda, V.T.; Onah, R.E. 2017. Nutritional profile of soaked Cajanus cajan (L.) Millsp. and its utilization as partial replacement for soybean meal in the diet of Clarias gariepinus (Burchell, 1822) fingerlings. Journal of Applied Ichthyology 33: 450-457.

Teixeira, B.; Machado, C.C.; Fracalossi, D.M. 2010. Exigência proteica em dietas para alevinos do dourado (Salminus brasiliensis). Acta Scientiarum. Animal Sciences 32: 33-38.

Ugolev, A.M.; De Laey, P. 1973. Membrane digestion: a concept of enzyme hydrolysis on cell membranes. Biochimica et Biophysica Acta 300: 105-128.

Walker, A.B.; Sidor, I.F.; O'Keefe, T.; Cremer, M.; Berlinsky, D.L. 2012. Partial replacement of fishmeal with soybean meal and soy protein concentrate in diets of Atlantic Cod. North American Journal of Aquaculture 74: 330-337.

Wang, Y.R.; Wang, L.; Zhang, C.X.; Song, K. 2017. Effects of substituting fishmeal with soybean meal on growth performance and intestinal morphology in orange-spotted grouper (Epinephelus coioides). Aquaculture Reports 5: 52-57.

Watson, A.M.; Buentello, A.; Place, A.R. 2014. Partial replacement of fishmeal, poultry by-product meal and soy protein concentrate with two non-genetically modified soybean cultivars in diets for juvenile cobia, Rachycentron canadum. Aquaculture 434: 129136.

Wilson, J.M.; Castro, L.F.C. 2011. Morphological diversity of the gastrointestinal tract in fishes. In: Grossell, M.; Farrell, A.P.; Brauner, C.J., eds. The multifunctional gut of fish. Elsevier, Amsterdam, The Netherlands.

Yaghoubi, M.; Mozanzadeh, M.T.; Marammazi, J.G.; Safari, O.; Gisbert, E. 2016. Dietary replacement of fishmeal by soy products (soybean meal and isolated soy protein) in silvery-black porgy juveniles (Sparidentex hasta). Aquaculture 464: 50-59. 